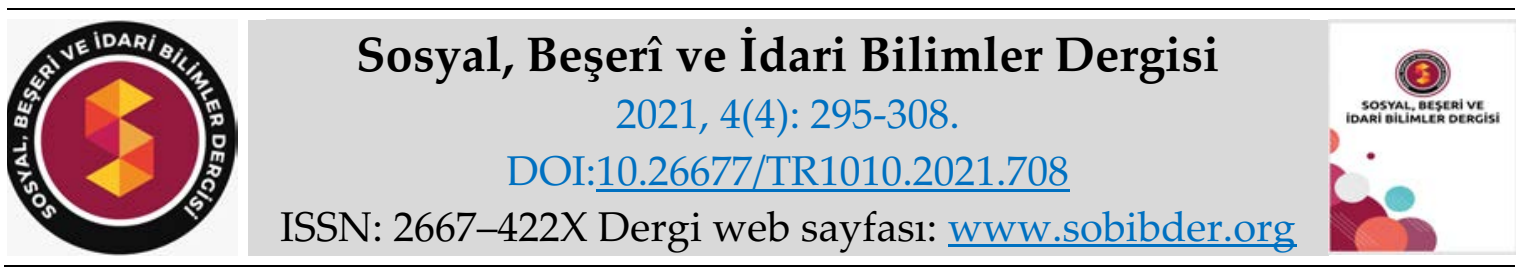

ARAȘTIRMA MAKALESI

\title{
Öğretmenlerde Meslektaş İlişkilerinin Tükenmişlik Duygusuna Etkisi
}

Bihter YILDIRIM, Yüksek Lisans Öğrencisi, İstanbul Ticaret Üniversitesi, Sosyal Bilimler Enstitüsü, İstanbul, e-posta: bihteryildirim.77@icloud.com

ORCID: https://orcid.org/0000-0003-2717-8848

Doç. Dr. Osman BAYRAKTAR, İstanbul Ticaret Üniversitesi, İşletme Fakültesi, İstanbul, e-posta: obayraktar@ticaret.edu.tr

ORCID: https://orcid.org/0000-0003-2502-3578

Öz

$\mathrm{Bu}$ araştırmanın temel hipotezi, meslektaş ilişkileri ölçek puanlarının, tükenmişlik duygusunu ölçek puanlarını etkilediği biçiminde belirlenmiştir. Temel hipotezin dışında, katılımcıların demografik faktör düzeyleri ile tükenmişlik algısı arasında istatiksel olarak anlamlı farklılıklar olduğu varsayımına ilişkin hipotezler test edilmiştir. Meslektaş ilişkileri kavramsal yapısını ölçmek için Oranje (2011) tarafından geliştirilen Meslektaş İlişkisi Algısı Ölçeği, tükenmişlik kavramsal yapısını ölçmek için Maslach ve Jackson (1981) tarafından geliştirilen Maslach Tükenmişlik Ölçeği kullanılmıştır. Her iki ölçek de Likert tipi ve beş düzeylidir. Araştırma Yalova ilinde görev yapan öğretmenler arasında gerçekleştirilmiştir. Veriler kolayda anket yöntemi ile toplanmış, araştırmaya cevap veren katılımcılardan 313'ünün verileri istatistik analiz için uygun bulunmuştur. Toplanan veriler, IBM SPSS 22.0 yazılım programı ile analiz edilmiştir. Analizler sonucunda meslektaş ilişkileri ile tükenmişlik arasında anlamlı ve negatif bir ilişki tespit edilmiş ve temel hipotez doğrulanmıştır. Katılımcıların yaş düzeyleri, medeni durum, çocuk sayısı, çalışma kıdemi ve eğitim düzeyinden oluşan demografik özellikler ile tükenmişlik arasında istatistiksel olarak anlamlı bir ilişki tespit edilememiş, ikincil düzeyde $\mathrm{Ho}$ hipotezleri reddedilememiş̧ir. İlgili yazın incelendiğinde meslektaş ilişkileri ile tükenmişlik duygusu ilişkisini ele alan çalışmaya rastlanılmamıştır. Araştırmanın bu yanıyla ilgili alanyazın açısından özgün olduğu düşünülmektedir.

Anahtar Kelimeler: Meslektaş İlişkileri, Tükenmişlik, Öğretmenler.

Makale Gönderme Tarihi: 04.12.2020

Makale Kabul Tarihi: 01.04.2021

\section{Önerilen Atıf:}

Yıldırım, B. ve Bayraktar, O. (2021). Öğretmenlerde Meslektaş İlişkilerinin Tükenmişlik Duygusuna Etkisi, Sosyal, Beşeri ve İdari Bilimler Dergisi, 4(4): 295-308.

(C) 2021 Sosyal, Beşerî ve İdari Bilimler Dergisi. 


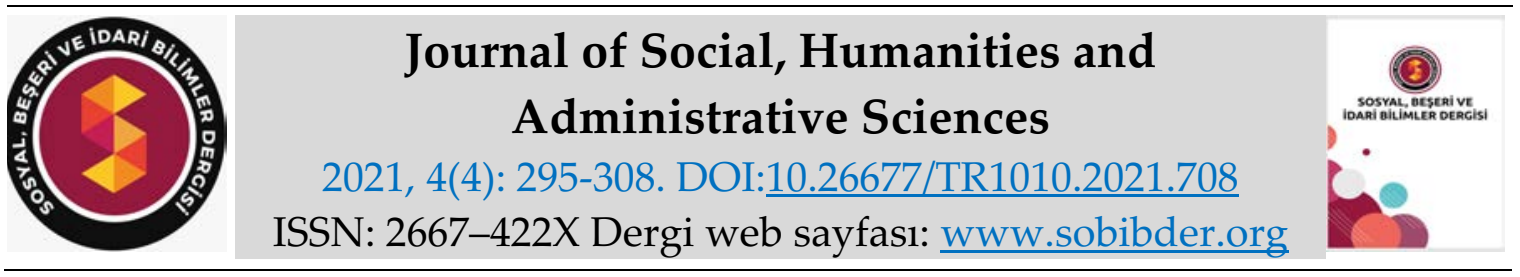

RESEARCH PAPER

\title{
The Effect of Colleague Relationships on the Feeling of Burnout in Teachers
}

Bihter YILDIRIM, MSc. Student, İstanbul Commerce University, Social Sciences Institute, İstanbul, e-mail: bihteryildirim.77@icloud.com ORCID: https://orcid.org/0000-0003-2717-8848

Associate Prof. Dr. Osman BAYRAKTAR, İstanbul Commerce University, Faculty of Management, İstanbul, e-mail: obayraktar@ticaret.edu.tr

ORCID: https://orcid.org/0000-0003-2502-3578

\begin{abstract}
The main hypothesis of this study is that the scores of the colleague relations scale affect the sense of burnout on the scale scores. Apart from the main hypothesis, the hypotheses related to the assumption that there are statistically significant differences between the demographic factor levels and burnout perception of the participants were tested. The Colleague Relationship Perception Scale developed by Oranje (2011) to measure the conceptual structure of colleague relationships, and the Maslach Burnout Scale developed by Maslach and Jackson (1981) were used to measure the conceptual structure of burnout. Both scales are Likert type and five-level. The research was conducted among the teachers working in the province of Yalova. The data were collected with the easiest questionnaire method, and the data of 313 of the participants who answered the research were found suitable for statistical analysis. Collected data were analyzed with IBM SPSS 22.0 software program. As a result of the analysis, a significant and negative relationship between colleague relations and burnout was determined and the main hypothesis was confirmed. No statistically significant relationship was found between burnout and the demographic characteristics of the participants, consisting of age levels, marital status, number of children, working seniority, and education level, and H0 hypotheses at secondary level could not be rejected. When the related literature is examined, there is no study dealing with the relationship between colleague relations and the feeling of burnout. It is thought to be unique in terms of the literature regarding this aspect of the research.
\end{abstract}

Keywords: Colleague Relations, Burnout, Teachers.

Received: 04.12.2020

Accepted: 01.04.2021

\section{Suggested Citation:}

Yıldırım, B. and Bayraktar, O. (2021). The Effect of Colleague Relationships on the Feeling of Burnout in Teachers, Journal of Social, Humanities and Administrative Sciences, 4(4): 295-308.

(c) 2021 Sosyal, Beşerî ve İdari Bilimler Dergisi. 


\section{Gíriş}

İnsanlar günün büyük bir kısmını çalışma hayatlarında geçirmektedir. Birey gün içinde beraber olunan çalışma arkadaşları tarafından kabul görerek, sosyalleşmeye, iletişim kurmaya, desteklenmeye ihtiyaç duymaktadır. Meslektaş ilişkileri, öğretmenlerin tükenmişlik düzeyleri ve tükenmişlik kavramlarının alt grupları olan duygusal tükenme, duygusuzlaşma, kişilik duyusunda azalma üzerinde önemli bir etkiye sahiptir.

Günümüzde sıkça karşılaştığımız popüler araştırma konularından biri olan tükenmişlik uzun süren yoğun duygusal taleplere ve strese maruz kalınmasına bağlı olarak ortaya çıkmaktadır. Tükenmişliğin diğer mesleklere oranla her gün meslektaşları ve öğrencileri ile yüz yüze ilişki kurması, etkili iletişim gerektirmesi ve duygusal olarak bireyi tüketmesi nedeni ile eğitim sektöründe olan öğretmenlerde ortaya çıkma olasılığı daha yüksektir. İleri seviyelerde yaşanan tükenmişlik kişinin meslektaşlarına karşı duyarsızlaşmasına neden olmaktadır.

Yapılan bu çalışmada meslektaş ilişkileri ile tükenmişlik kavramlarına ve kavramlar üzerine yapılan araştırmalara yer verilmiştir. Bununla birlikte istatistiksel çalışmalarla; tükenmişliğin alt boyutları ile meslektaş ilişkileri arasında ve yine yaş, medeni durum, çocuk sayısı, kıdem ve eğitim seviyesi ile tükenmişlik arasında ilişki olup olmadı̆̆ belirlenmeye çalışılmıştır.

\section{ALAN YAZIN}

\section{Tükenmişlik Kavramı Tanımı ve Gelişimi}

Türkan'a (2014: 283) göre, tükenmişlik ilk kez 1974 yılında Herbert Freudenberger tarafından "başarısız olma, yıpranma, enerji ve gücün azalması veya tatmin edilemeyen istekler sonucunda kişinin iç kaynaklarında meydana gelen tükenme durumu" şeklinde tanımlanmaktadır. Günümüzde ise tükenmişlik kavramı üzerine en yaygın ve kabul gören tanım Christina Maslach'a aittir. Maslach'a göre tükenmişlik “işi gereği yoğun duygusal taleplere maruz kalan ve sürekli diğer insanlarla yüz yüze çalışmak durumunda olan kişilerde görülen fiziksel bitkinlik, uzun süreli yorgunluk, çaresizlik ve umutsuzluk duygularının, yapılan işe, hayata ve diğer insanlara karşı olumsuz tutumlarla yansıması ile oluşan bir sendrom"dur (Yılmaz, 2018: 29).

\section{Tükenmişlik Sendromu Boyutları}

Tükenmişlik kavramı boyutları Maslach ve arkadaşları tarafından geliştirilen bir modelden oluşmaktadır. Tükenmişlik kavramı; duygusal tükenme, duyarsızlaşma, kişisel başarı duyusunda azalma olarak üç başlık altında toplanmaktadır (Helvacı ve Turhan, 2013:59).

\section{Duygusal Tükenme}

Duygusal tükenme çalışanların yorgunluk ve ruhsal yıpranma düzeylerindeki artış şeklinde yorumlanmaktadır (Bitmiş vd., 2013:31). Tükenmişliğin en belirgin boyutudur. Bir süre sonra kişi istemediği duygusal taleplerle karşılaştığı zaman kendisini yorgun hissetmeye başlamaktadır (Fettahlığlu, 2015:182). 


\section{Duyarsızlaşma}

Duyarsızlaşma tükenmişliğin kişiler arasındaki boyutudur. Kişi çevresindekilere karşı mesafe koymakta veya olumsuz tavırlar sergilemektedir (Çivici, 2016:134).

\section{Kişilik Duyusunda Azalma}

Tükenmişliğin üçüncü boyutu olan kişisel başarısızlık duygusu; kişinin kendisini, göstermiş olduğu performansını olumsuz yönde eleştirmesi ve özgüven kaybı yaşamasını ifade etmektedir (Aktaş ve Şimşek, 2015:208). Olumsuz düşüncelerin sonucunda birey etrafında bulunan kişiler ile mümkün olduğunca daha az iletişime geçmenin yolunu tercih etmektedir (Eroğlu, 2014:150).

\section{Tükenmişlik Belirtileri}

Tükenmişlik sendromu ani bir şekilde oluşan bir durum değildir, uzun zaman içerisinde yaşanan belirtilerin birleşmesiyle gerçekleşmektedir (Diri, 2015:9). Tükenmişlik belirtileri kişiden kişiye farklılıklar göstermektedir (Köse, 2014:33). Yaşanan belirtilerin tükenmişlik dereceleri de aynı şekilde bireye göre farklılaşmaktadır (Toğa, 2016:27). Tükenmişlik sendromunun bir çok belirtisi vardır fakat en açık belirtisi bireyin hayattaki anlamın ve isteklerin yok olduğunu düşünerek kendini bitkin bir hale dönüştürmesidir (Gülova vd., 2014:28).

Kişinin belirtilerden kaçması ve üstüne gitmemesi sonucunda tükenmişlik boyutu ilerleme göstermektedir. Tükenmişlik sürecinin ilerlememesi, farklı düzeylere taşınmaması için belirtilerin farkına varılarak zamanında müdahale yapılması büyük önem teşkil etmektedir (Kalkızoğlu, 2018:11). Tükenmişlik sendromu belirtileri; fiziksel, psikolojik ve davranışsal olarak üç boyut altında incelenmektedir (Akdağ, 2018:10).

\section{Tükenmişliğe Neden Olan Faktörler}

Tükenmişliği etkileyen faktörler bireysel, örgütsel ve çevresel olarak üç başlık altında toplanmaktadır.

\section{Bireysel Faktörler}

Tükenmişlik günümüzde mesleki bir sorun haline gelmektedir. Mesleki tükenmişlik her meslek alanında gözlemlenmekte, çoğunlukla hizmet alanında ki sektörleri kapsadığ gözlemlenmektedir (Ören, 2018:4). Tükenmişliğin bireysel faktörleri her bireyde farklılık göstermektedir. Tükenmişliğe etki eden bireysel faktörler: yaş, cinsiyet, medeni durum, eğitim seviyesi, kişilik yapısı, kişisel beklentilerden oluşmaktadır (Deran ve Beller, 2015:70).

\section{Örgütsel Faktörler}

Tükenmişlik bireylerin çalışma hayatını ve yaşantısını etkilemektedir. Maslach ve Letier'e göre örgütsel faktörler iş yükü, aidiyet, adalet, ödüller, kontrol, değerler başlıklarından oluşmaktadır (Engizek vd., 2017:113). 


\section{Çevresel Faktörler}

Çevresel faktörler, örgütün ve kişinin sosyal çevresini içermektedir (Turgut, 2014: 20). Kişinin çevresiyle olan ilişkilerinde sürekli olumsuzluklar yaşaması tükenmişlikten çıkarak hastalık haline dönüşmektedir (Akıllıŏlu, 2017:9).

\section{Tükenmişlik Sendromu Oluşma Süreci}

Gerçekleşen tükenmişlik süreci belirli bir zaman dilimini kapsamakta ve birbirini kesintisiz şekilde takip etmektedir (Düz, 2015:45). Şevk ve coşku aşaması, durağanlaşma aşaması, engellenme aşaması ve umursamazlık aşaması olarak dört temel evreden geçmektedir (Koyuncu, 2015:64).

\section{Tükenmişlikle Başa Çıkma Yöntemleri}

Tükenmişlik ile mücadele edilmek ve mücadeleden sonuç alabilmek için öncelikle var olan problemi kabul etmek gerekmektedir. Tükenmişlik sendromu çalışma hayatında büyük bir sorun oluşturmaktadır (Elçikoca, 2018:16) . Bu sorunu en aza indirgemek için bireysel ve örgütsel olarak mücadele etmek gerekmektedir (Dülger, 2014: 65).

\section{Bireysel Düzeyde Başa Çıkma Yöntemleri}

Çözüm getirebilmek için kendini tanımak, huzurlu yaşam tarzını benimsemek, beslenme alışkanlıklarını düzenlemek, sağlıklı yaşamak, dinlenmek, tatile çıkmak, çevreden danışmanlık destekleri almak, hedefleri gerçekçi boyutlarda belirlemek, hayatında olumsuzluklara yer vermemek, ailesi ve çalışma hayatında denge kurmak, kötü alışkanlıklardan uzak durmak, sevdiği işi yapmak bireyin bu süreci atlatmasına yardımcı olmaktadır (Ardıç ve Polatcı, 2008: 76).

\section{Örgütsel Başa Çıkma Yöntemleri}

Tükenmişlik sendromu ilk olarak birey üzerinde etki etmekte daha sonrasında ise birey yoluyla örgütleri de etkileyerek büyük zararlara yol açabilmektedir. Bu nedenle örgüt içerisinde gerekli tedbirlerin alınması, tükenmişliğin önlenmesine yardımcı olmaktadır (Güney ve Akdağ, 2018:449). Örgütsel tükenmişlikle baş edebilmek için; örgütte doğru ve adaletli bir yönetim sistemini oluşturulmak (Koç, 2019:35), kişinin kendini gerçekleştirebilmesi için kariyer fırsatları yaratmak, kişisel gelişim eğitimleri vermek, danışmanlık hizmeti sağlamak, rol belirsizliklerini önlemek (İraz ve Ganiyusufoğlu, 2011:445), sağlıklı iletişim kanalları kurmak, terfi ve ödül sistemlerinde adaletli olmak, çalışma saatlerinde molalar vermek, çalışma koşullarını iyileştirmek gerekmektedir (Tekiner Tozduman, 2016:32).

\section{Meslektaş İlişkileri Kavramı}

İnsanlar meslek seçimlerinde kişilik yapılarını ve yeteneklerini göz önünde bulundurarak, çalışırken iş doyumu sağlayabileceği meslekleri seçmektedirler. Bireyin karakterine uyumlu mesleği icra etmesi mutlu çalışmasına sebebiyet vermektedir. Meslek seçimini doğru yapmak 
kişinin fiziksel ve psikolojik olarak kendini iyi hissetmesini sağlar. Meslekteki benzer rütbeye (Hertzog vd., 2000:5) sahip olan bireyler meslektaş olarak tanımlanmaktadır (Gürcan, 2019:16).

Meslektaşlık karşılıklı sevgi ve iyiliğe dayalı kardeşlik içindeki insanların sosyal birliğidir (Gürcan, 2019:16). İnsanların ortak bilinç içerisinde toplanmasını ve kolektif bir anlaşmayı ifade eder. İş ortamını etkileyen en önemli faktörlerden birini meslektaş ilişkileri oluşturmaktadır. Meslektaş ilişkileri aynı zamanda çalışan bireylerin işlerini sevmemesi durumu bile çalışma arkadaşlarından dolayı mutluluk duyarak (Özaslan Çalışkan, 2018:95), işinden zevk almasını sağlamaktadır (Eser, 2010: 63).

\section{Öğretmenlerde Tükenmişlik Duygusu ile Meslektaş İlişkileri Arasındaki İlişkiler}

Kişi çalıştığı yerden yalnızca başarı ve para beklememektedir (Özaydın ve Özdemir, 2014:254). Beraber gün içerisinde vakit geçirdiği çalışma arkadaşları tarafından kabul görerek desteklenmeye ihtiyaç duymaktadır (Karakuzu, 2019:34). Hayatlarının büyük çoğunluğunu iş yerinde geçiren kişi iş veya herhangi bir mevzu ile ilgili kendisini başarısız ya da kötü hissettiğinde kaygılarından kurtulmak adına tavsiye almak, akran olarak gördükleri meslektaşları ile yardımlaşmak istemektedir (Gürcan, 2019:15). Çünkü aynı işi icra eden meslek üyeleri de benzer sorunları yaşadıkları için kendisine katkıda bulunabilecek kişi yine meslektaşlarıdır (Çetinkaya Ulusoy, 2010:8).

Çalışana destek sağlamayan iş arkadaşları, stres kaynağı ve tükenmişliğe eğilim yaratan bir faktörün temelini oluşturmaktadır. Huzursuz meslektaş ilişkilerinde bireyin motivasyonunda düşüklük, stres ve depresyon düzeyinde artış, meslekten soğuma, tükenmişlik gözlemlenmektedir. İleri seviyelerde yaşanan tükenmişlik kişinin meslektaşlarına karşı duyarsızlaşmasına neden olmaktadır. Yapılan bazı araştırmalarda tükenmişliğin diğer mesleklere oranla her gün meslektaşları ve öğrencileri ile yüz yüze ilişki kurması, etkili iletişim gerektirmesi ve duygusal olarak bireyi tüketmesi nedeni ile eğitim sektöründe olan öğretmenlerde ortaya çıkma olasılığı daha yüksektir (Bıçak, 2018:25).

\section{Önceki Bazı Araştırmalar ve Hipotezlerin Geliştirilmesi}

Murat (2016), meslektaşları ile uyumlarını değerlendirme derecesine göre üniversite öğretim elemanlarının tükenmişlikleri incelendiğinde; üç alt boyutta da "duygusal, kişisel başarı ve duyarsızlaşma" tükenmişlik düzeyleri arasındaki fark anlamlı bulunmuştur. Elde edilen verilere bakıldığında; meslektaşları ile uyumlarını "çok iyi" olarak görenlerin "zayıf olarak görenlere oranla üç alt boyutta da tükenmişlik düzeylerinin daha düşük olduğu görülmüştür. Çalışılan örgüt ikliminin kişilerin psikolojileri üzerinde etkili olacağı düşünülmüştür. Üniversite öğretim elemanlarının sorun alarak gördükleri durumlardan üçüncü sırayı "öğretim elemanları arasındaki ilişkiler" in alması bu sonucu doğrular nitelikte bulunmuştur. Tükenmişliğin insanlarla yüz yüze ilişkilerde bulunan mesleklerde görülen bir sendrom olduğu dikkate alınırsa meslektaşları ile uyumun tükenmişlik düzeyini etkilemesi anlamlı olarak yorumlanabilir.

Özaslan Çalışkan (2018), yılında yapmış olduğu araştırmada İş Stresi, Meslektaş İlişkileri ve Bireysel Performans ilişkileri incelendiğinde Regresyon analizi bulgularına göre; çalışanların iş stresinin bireysel performansları üzerinde negatif bir etkisi olduğu, meslektaş ilişkilerinin bireysel performans üzerinde pozitif bir etkisi olduğu ortaya çıkmıştır. Eser (2010), yılında 
yaptığ1 okul öncesi öğretmenlerinde iş doyumu, meslektaş ilişkileri ve okul idaresi desteği arasındaki ilişkilerin incelenmesi sonucunda araştırmada, katılımcıların iş doyumunun hem meslektaş ilişkileri hem de algilanan idareci desteği ile olumlu yönde anlamlı ilişkilere sahip olduğu görülmüştür. Meslektaş ilişkileri ve idareci desteğine ilişkin olumlu değerlendirmeler arttıkça iş doyumu da artmıştır. Çalışmadan çıkan bir diğer sonuç da meslektaş ilişkileri ve idareci desteğinin iş doyumunu etkilediği, ancak okulun yeri, yaş, hizmet yılı ve eğitim düzeyi değişkenlerinin ise iş doyumu üzerinde etkili olmadığıdır.

Öğretmenlerin meslektaş ilişki düzeylerinin tükenmişlik düzeyleri üzerindeki etkisini test etmek amacıyla temel hipotezler aşağıdaki şekilde belirlenmiştir:

$\mathbf{H}_{1}$ : Öğretmenlerin meslektaş ilişki düzeylerinin tükenmişlik düzeyleri üzerinde etkisi vardır.

$\mathbf{H}_{1, a:}$ Öğretmenlerin meslektaş ilişki düzeylerinin duygusal tükenmişlik düzeyleri üzerinde etkisi vardır.

H1,b: Öğretmenlerin meslektaş ilişki düzeylerinin duyarsızlaşma düzeyleri üzerinde etkisi vardır.

$\mathbf{H}_{1, \mathrm{c}}$ : Öğretmenlerin meslektaş ilişki düzeylerinin düşük kişisel başarı his düzeyleri üzerinde etkisi vardır.

\section{AMAÇ ve YÖNTEM}

Araştırmanın asıl amacı Öğretmenlerde Meslektaş İlişkilerinin Tükenmişlik Duygusuna Etkisinin derecesinin ne olduğunu belirlemektir. Araştırmada asıl amacın yanında öğretmenlerin meslektaş ilişki ve tükenmişlik düzeylerinin medeni durum, yaş, mesleki kıdem ve eğitim düzeylerine göre farklılaşıp farklılaşmadığı da araştırma kapsamında tutulmuştur. Bu çalışma ile meslektaş ilişkileri ve tükenmişlik kavramlarına, bu iki kavram üzerine yapılan çalışmalara ve istatistiksel değerlere yer verilmiştir. Alan yazın çalışmalarına bakıldığında, "Öğretmenlerde Meslektaş İlişkilerinin Tükenmişlik Duygusuna Etkisi" başlı̆̆ı altında eğitim sektöründe çalışma yapılmadığı görülmüştür. Çalışmanın amacı; Öğretmenlerin meslektaş ilişki düzeyleri ile tükenmişlik arasındaki ilişkinin niteliğini açıklamak, tanımlamak ve varsa ilişkinin gücünü belirlemektir.

Araştırmanın evrenini, Yalova'da faaliyet gösteren beş ortaokul ve lise düzeyde ki eğitim kurumunun öğretmenleri oluşturmaktadır. Bilgi toplama aracı olarak, girişte kaynağı belirtilen iki ölçek kullanılmıştır. Tükenmişlik ölçeğinde 22, meslektaş ilişkisi algısı ölçeğinde ise 6 olmak üzere toplam 28 ifade yer almaktadır. Anket formunda ayrıca 5 adet demografik soruya yer verilmiştir. Beş dereceli Likert tipi ifadeler olumsuzdan başlayıp olumluya doğru " Hiç Doğru değil”, “Doğru Değil”, "Kararsızım”, “Doğru” ve "Çok Doğru” şeklinde sinıflandırılmıştır.

Katılımcıların anket çalışmasına gönüllü olarak katılmaları ve anketi tedirginlik hissetmeden yanıtlamaları araştırmanın birinci ön kabulüdür. Bu sonuca ulaşılmasında çalışmanın bilimsel bir nitelik taşıması sebebiyle katılımcılara ait bilgilerin anonim olarak tutulacağı bilgisinin açıça belirtilmiş olması etkili olmuştur. Bu sayede anket formunda yer alan soru ve ifadelerden doğru sonuçlar elde edilebilmesi sağlanmıştır. Seçilen örnek ana kütlenin, bulunduğu kurumdaki ana kütleyi temsil edebilmesi araştırmanın ikinci ön kabulüdür. 
Anket uygulaması 5 Eylül - 2 Ekim 2019 tarihleri arasında gerçekleştirilmiş olup, eğitim sektöründe görev alan 300 öğretmenin katılım sağlaması hedeflenmiştir. Planlanan zaman aralıkları dahilinde 313 kişinin katılım sağlamasıyla örneklem hedefine ulaşılmıştır.

Araştırma kapsamında elde edilen veriler, IBM SPSS 22.0 yazılım programı ile analiz edilmiştir. Ölçeklere ait yapısal geçerliliklerin denetlenmesi amacıyla açımlayıcı faktör analizi, güvenilirlik düzeylerinin belirlenmesi amaciyla ise Cronbach's Alpha güvenilirlik uygulamaları analizi yapılmıştır. Katılımcılara ait demografik ve tanımlayıcı istatistikler yapılarak araştırmanın değişkenlerini oluşturulan Likert ölçeklerden elde edilen ölçek ve boyut değerlerine ait betimsel istatistikler ve normal dağılım testleri yapılmıştır. Hipotezlerin incelenmesi amacıyla ilk önce meslektaş ilişkileri ölçeğinin açıklayıcı, tükenmişlik ölçeği toplamının ise açıklanan değişken olarak yer aldığı bir basit regresyon modeli, daha sonra yine meslektaş ilişkileri ölçeğinin açılayıcı değişken olarak tanımladığı, tükenmişlik ölçeği alt boyutlarının açıklanan değişken olarak tanımlandığı üç adet basit regresyon modeli kurulup çözümlenmiştir. Regresyon analizleri öncesi değişkenler arasındaki ilişkiler bakımından fikir verebilmesi amacıyla değişkenler arasında korelasyon analizi yapılmıştır.

\section{BULGULAR}

\section{Demografik Değişkenlere İlişkin Bulgular}

Öğretmenlerin medeni durumlarına göre dağılımları şu şekildedir; 80.7\% evli (n=238), 19.3\% bekâr (n=57). Öğretmenlerin yaş gruplarına göre dağılımları şu şekildedir; 14.9 \% 21-30 yaş $(\mathrm{n}=44), 30.2 \%$ 31-40 yaş $(\mathrm{n}=89), 54.9 \% 41+$ yaş $(\mathrm{n}=162)$. Öğretmenlerin çocuk sayılarına göre dağılımları şu şekildedir; $23.4 \%$ yok ( $\mathrm{n}=69), 29.2 \% 1 \quad(\mathrm{n}=86), 47.5 \% 2$ ve daha fazla $(\mathrm{n}=140)$. Öğretmenlerin mesleki kıdem sürelerine göre dağılımları şu şekildedir; $23.4 \% 4$ yıldan az $(n=69)$, $21.7 \% 5-9$ yıl arası $(n=64), 18.3 \% 10-14$ yıl arası $(n=54), 15.3 \% 15-19$ yıl arası $(n=45), 21.4 \% 20$ yıl ve üzeri ( $n=63)$. Öğretmelerin eğitim sürelerine göre dağılımları şu şekildedir; 89.2\% lisans ( $n=263)$, $10.8 \%$ lisansüstü $(\mathrm{n}=32)$.

Araştırmanın ölçme araçları olan ölçeklerde yer alan ters soruların ters yönlü kodlanmasının ardından sorulara verilen cevapların ortalamasından elde edilen ölçek değerlerine ait betimsel istatistikler Tablo 1'deki gibidir.

Tablo 1. Ölçek Betimsel İstatistikleri

\begin{tabular}{lccccc}
\hline Değişken & N & Minimum & Maksimum & $\overline{\boldsymbol{X}}$ & S.S \\
\hline \hline Duygusal Tükenmişlik & 295 & 1.000 & 3.600 & 2.229 & 0.546 \\
Duyarsızlaşma & 295 & 1.000 & 3.556 & 2.210 & 0.545 \\
Düşük Kişisel Başarı Hissi & 295 & 1.000 & 3.667 & 2.209 & 0.533 \\
Toplam Tükenmişlik & 295 & 1.000 & 3.574 & 2.216 & 0.537 \\
Meslektaş İlişkileri & 295 & 2.000 & 5.000 & 3.903 & 0.722 \\
& & & & & \\
\hline \hline
\end{tabular}


Duygusal tükenmişlik alt boyutu minimum 1, maksimum 3.6, ortalama 2.229 ve 0.546 standart sapma değerine sahiptir. Duyarsızlaşma alt boyutu minimum 1, maksimum 3.556, ortalama 2.210 ve 0.545 standart sapma değerine sahiptir. Düşün kişisel başarı hissi alt boyutu minimum 1, maksimum 3.667, ortalama 2.209 ve 0.533 standart sapma değerine sahiptir. Tükenmişlik ölçeği minimum 1, maksimum 3.574, ortalama 2.216 ve 0.537 standart sapma değerine sahiptir. Meslektaş ilişkileri ölçeği minimum 2, maksimum 5, ortalama 3.903 ve 0.722 standart sapma değerine sahiptir. Ölçek ve alt boyutlara ait normal dağılım istatistikleri ise Tablo 2' deki gibidir.

Tablo 2. Ölçek Normal Dağılım Test İstatistikleri

\begin{tabular}{|c|c|c|c|c|c|c|c|c|}
\hline \multirow{2}{*}{ Değişken } & \multicolumn{3}{|c|}{ Kolmogorov-Smirnov } & \multicolumn{3}{|c|}{ Shapiro-Wilk } & \multirow{2}{*}{$S$} & \multirow{2}{*}{$\mathbf{K}$} \\
\hline & İst. & S.D & Sig. & İst. & S.D & Sig. & & \\
\hline Duygusal Tükenmişlik & 0.050 & 295 & 0.074 & 0.993 & 295 & 0.188 & 0.037 & -0.344 \\
\hline Duyarsızlaşma & 0.048 & 295 & 0.066 & 0.991 & 295 & 0.084 & 0.053 & -0.282 \\
\hline Düşük Kişisel Başarı Hissi & 0.051 & 295 & 0.200 & 0.993 & 295 & 0.191 & 0.035 & -0.474 \\
\hline Toplam Tükenmişlik & 0.047 & 295 & 0.200 & 0.993 & 295 & 0.203 & 0.025 & -0.375 \\
\hline Meslektaş İlişkileri & 0.146 & 295 & 0.000 & 0.942 & 295 & 0.000 & -0.649 & -0.290 \\
\hline
\end{tabular}

Tablo incelendiğinde normal dağılım test istatistikleri anlamlılık değerlerine göre Meslektaş ilişkileri ölçeği dışındaki tüm değişkenlerin \%5 anlamlılık düzeyinde normal dağıldığ görülmektedir. Diğer yandan meslektaş ilişkileri ölçeğinin çarpıklık katsayısı incelendiğinde ise değişkeninin aşırı çarpık olmadığı ve normal dağılıma yakın olduğu söylenebilir. $(S<1.5)$ (Tabachnick ve Fidell, 2013, s. 96) Bu şartlar altında değişkenler ile yapılacak hipotez testlerinde normal dağılım varsayımında bulunulan regresyon, $f$ testi ve bağımsız örneklem $t$-testi gibi parametrik analizlerin güvenilir bir şekilde uygulanabileceğine karar verilmiştir.

\section{Hipotez Testlerine İlişkin Bulgular}

Hipotezlerin incelenmesi amacıyla ilk önce meslektaş ilişkileri ölçeğinin açılayıcı, tükenmişlik ölçeği toplamının ise açıklanan değişken olarak yer aldığı bir basit regresyon modeli, daha sonra yine meslektaş ilişkileri ölçeğinin açıklayıcı değişken olarak tanımladığı, tükenmişlik ölçeği alt boyutlarının açıklanan değişken olarak tanımlandığı üç adet basit regresyon modeli kurulup çözümlenmiştir. Regresyon analizleri öncesi değişkenler arasındaki ilişkiler bakımından fikir verebilmesi amacıyla değişkenler arasında korelasyon analizi yapılmıştır.

Tablo 3 incelendiğinde tükenmişlik ölçeği alt boyutları arasındaki korelasyon katsayılarının istatistiksel olarak \%5 anlamlılık düzeyinde anlamlı pozitif ve 0.968 ile 0.994 arasında değiştiği görülmektedir. (0.968 $\leq \mathrm{Rxy} \leq 0.994)$. Bu durumda tükenmişlik ölçeği alt boyutları arasında oldukça yüksek ve aynı yönde bir birlikte değişirlik ilişkisi olduğu söylenebilir $(0.9 \leq|R x y|)$. Diğer yandan tükenmişlik ölçeği ve alt boyutları ile meslektaş ilişkileri ölçeği arasındaki korelasyon ilişkileri incelendiğinde ise tüm katsayıların $\% 5$ anlamlılık düzeyinde istatistiksel olarak anlamlı negatif ve -0.472 ile -0.561 arasında değiştiği görülmektedir. $(-0.561 \leq \mathrm{R} x \mathrm{x} \leq-0.472)$. Bu durumda tükenmişlik ölçeği ve alt boyutları ile meslektaş ilişkileri arasında ters yönlü ve orta düzeyde birlikte değişirlik ilişkileri olduğu söylenebilir. $(0.4 \leq|\mathrm{Rxy}| \leq 0.6)$. Meslektaş ilişkileri ölçeğinin 
açıklayıcı, tükenmişlik ölçeği toplamının ise açıklanan değişken olarak yer aldığı bir basit regresyon modeli çözümlemelerine dair bulgular Tablo 4 'teki gibidir.

Tablo 3. Değişkenler Arası Korelasyon Matrisi

\begin{tabular}{lllcccc}
\hline Değişken & İstatistik & $\mathbf{1}$ & $\mathbf{2}$ & $\mathbf{3}$ & $\mathbf{4}$ & $\mathbf{5}$ \\
\hline \hline Duygusal & Rxy & 1 & $0.972^{*}$ & $0.968^{*}$ & $0.988^{*}$ & $-0.472^{*}$ \\
Tükenmişlik & sig. & & 0.000 & 0.000 & 0.000 & 0.000 \\
\hline \multirow{2}{*}{ Duyarsızlaşma } & Rxy & & 1 & $0.990^{*}$ & $0.995^{*}$ & $-0.523^{*}$ \\
& sig. & & & 0.000 & 0.000 & 0.000 \\
\hline Düşük Kişisel & Rxy & & & 1 & $0.994^{*}$ & $-0.561^{*}$ \\
Başarı Hissi & sig. & & & & 0.000 & 0.000 \\
\hline Toplam & Rxy & & & & 1 & $-0.523^{*}$ \\
Tükenmişlik & sig. & & & & & 0.000 \\
\hline Meslektaş & Rxy & & & & & 1 \\
İlişkileri & sig. & & & & &
\end{tabular}

Not. $\% 5$ anlamlılık düzeyinde istatistiksel anlamlılığ ifade eder. Rxy: $X$ ve $Y$ gibi iki değişken arasındaki korelasyon katsayısını ifade eder.

Tablo 4. Regresyon Model Tahmini

\begin{tabular}{|c|c|c|c|c|c|}
\hline Bağımsız Değişken & $\beta$ & S. $H^{\mathrm{d}}$ & Standardize Edilmiş $\beta$ & $\mathbf{t}$ & $\mathbf{p}$ \\
\hline Meslektaş İlişkileri & -0.389 & 0.036 & -0.523 & $-10.807^{*}$ & 0.000 \\
\hline Sabit Terim & 3.735 & 0.139 & & $26.915^{*}$ & 0.000 \\
\hline \multicolumn{6}{|c|}{ Tanısal istatistikler } \\
\hline Determinasyon & & \multicolumn{2}{|r|}{$\mathbf{R}^{2}=0.274$} & \multicolumn{2}{|c|}{ D. $\mathbf{R}^{2}=0.271$} \\
\hline Uyum İyiliği & & \multicolumn{2}{|r|}{$F(1,293)=110.189^{*}$} & \multicolumn{2}{|c|}{$\mathrm{p}=0.000$} \\
\hline Breusch Pagan Deği & yans $T$ & \multicolumn{2}{|r|}{$\mathbf{F}(1,293)=2.747^{*}$} & \multicolumn{2}{|c|}{$\mathbf{p}=0.009$} \\
\hline Durbin Watson Oto & on Tes & \multicolumn{4}{|c|}{ D.W $=1.870$} \\
\hline
\end{tabular}

Not. ${ }^{*} 5$ anlamlılık düzeyinde istatistiksel olarak anlamlı ilişkileri ifade etmektedir. $\mathrm{d}$ üst imi dirençli standart hataları ifade eder. D.R²: Düzeltmiş determinasyon katsayısını ifade eder. (Parantez içleri test serbestlik derecelerini içerir.)

Tablo 4'te tanısal testler incelendiğinde Breusch Pagan Değişen Varyans Testine göre regresyon modelinde \%5 anlamlılık düzeyinde değişen varyans sorunu olduğu görülmektedir. $(F(1,293)$ $=2.747, \mathrm{p}<0.05)$. Durbin Watson test istatistiğinin ise 2 değerine oldukça yakın olduğu görüldüğ̈̈nden regresyon modelinde otokorelasyon sorunu olmadığ söylenebilir. (D.W=1.870 2).Modeldeki değişen varyans sorunundan kaynaklanabilecek etkinlik kaybının önüne geçmek amaciyla model dirençli standart hatalar yöntemi ile çözümlenmiştir.

Dirençli standart hatalar yöntemi ile tahmin edilen regresyon modeli için uyum iyiliği testi incelendiğinde regresyon modelinin $\% 5$ anlamlllık düzeyinde istatistiksel olarak anlamlı bir 
model olduğu söylenebilir. $(\mathrm{F}(1,293)=110.189$, $\mathrm{p}<0.05)$. Modelin düzeltilmiş determinasyon katsayısı ise meslektaş ilişkileri değişkeninin toplam tükenme ölçeğindeki değişimlerin yaklaşık $\% 27$ 'sini açıklayabildiğini göstermektedir.

Modelde tahmin edilen parametre incelendiğinde $\% 5$ anlamlılık düzeyinde istatistiksel olarak anlamlı ve negatif olduğu görülmektedir. $(\beta=-0.523, p<0.05)$. Bu durumda öğretmelerin mesleki ilişki düzeyleri artıkça tükenmişlik düzeylerinin azaldığı veya öğretmelerin mesleki ilişki düzeyleri azaldıkça tükenmişlik düzeylerinin arttı̆̆ı söylenebilir.

\section{SONUÇ ve ÖNERILLER}

Çalışma hayatındaki ortamın koşulları ve imkânları insan gücü olmadan bir anlam ifade etmemektedir. Aynı hedefler doğrultusunda bir araya gelen çalışanların meslektaş ilişkilerinin sağlıklı olması, fiziksel ve zihinsel olarak duygusal tükenme yaşamamaları adına önemli bir faktör teşkil etmektedir. Bu bağlamda çalışmada tükenmişlik sendromuna neden olan faktörler ve bunlarla başa çıkma yöntemleri ile meslektaş ilişkilerinin önemi ve üzerine yapılan araştırmalar değerlendirilmiştir.

Araştırmada katılımcıların Meslektaş ilişkileri kavramsal yapısını ölçmek için Oranje (2011) tarafından geliştirilen Meslektaş İlişkisi Algısı Ölçeği, tükenmişlik kavramsal yapısını ölçmek için Maslach ve Jackson (1981) tarafından geliştirilen Maslach Tükenmişlik Ölçeği kullanılmıştır. Her iki ölçek de Likert tipi ve beş düzeylidir.

Araştırmanın temel amacı "Öğretmenlerin Meslektaş İlişki Düzeyleri ile Tükenmişlik Duygusu” arasındaki ilişkinin test edilmesidir. Yapılan analizler sonrasında anlamlılık düzeyinde istatistiksel olarak anlamlı ve negatif olduğu görülmektedir. $(\beta=-0.523, p<0.05)$. Bu durumda öğretmelerin mesleki ilişki düzeyleri artıkça tükenmişlik düzeylerinin azaldığı veya öğretmelerin mesleki ilişki düzeyleri azaldıkça tükenmişlik düzeylerinin arttığı söylenebilir. Meslektaş İlişki düzeyleri ile tükenmişliğin alt boyutları olan "duygusal tükenme, duyarsızlaşma, düşük başarı hissi" arasındaki ilişkinin anlamlı ve negatif olduğu görülmektedir. Diğer bir deyişle öğretmelerin mesleki ilişki düzeyleri artıkça tükenme düzeylerinin azaldığı veya tersi bir ifade ile öğretmelerin mesleki ilişki düzeyleri azaldıkça tükenmişlik düzeylerinin arttığı söylenebilir.

Murat (2016) ise, meslektaşları ile uyumlarını değerlendirme derecesine göre üniversite öğretim elemanlarının tükenmişlikleri incelendiğinde; üç alt boyutta da "duygusal, kişisel başarı ve duyarsızlaşma" tükenmişlik düzeyleri arasındaki fark anlamlı bulunmuştur. Elde edilen verilere bakıldığında; meslektaşları ile uyumlarını "çok iyi" olarak görenlerin "zayıf olarak görenlere oranla üç alt boyutta da tükenmişlik düzeylerinin daha düşük olduğu görülmüştür.

Özaslan Çalışkan (2018), yılında yapmış olduğu araştırmada İş Stresi, Meslektaş İlişkileri ve Bireysel Performans ilişkileri incelendiğinde Regresyon analizi bulgularına göre; çalışanların iş stresinin bireysel performansları üzerinde negatif bir etkisi olduğu, meslektaş ilişkilerinin bireysel performans üzerinde pozitif bir etkisi olduğu ortaya çıkmıştır. Eser (2010), yılında yaptığı Okul öncesi öğretmenlerinde iş doyumu, meslektaş ilişkileri ve okul idaresi desteği arasındaki ilişkilerin incelenmesi sonucunda araştırmada, katılımcıların iş doyumunun hem meslektaş ilişkileri hem de algılanan idareci desteği ile olumlu yönde anlamlı ilişkilere sahip olduğu görülmüştür. Meslektaş ilişkileri ve idareci desteğine ilişkin olumlu değerlendirmeler 
arttıkça iş doyumu da artmıştır. Çalışmadan çıkan bir diğer sonuç da meslektaş ilişkileri ve idareci desteğinin iş doyumunu etkilediği, ancak okulun yeri, yaş, hizmet yılı ve eğitim düzeyi değişkenlerinin ise iş doyumu üzerinde etkili olmadığıdır.

Mevcut araştırmanın bir takım sınırlılıkları bulunmaktadır. Araştırma Yalova ilinde görev yapan öğretmenler arasında gerçekleştirilmiştir. Veriler kolayda anket yöntemi ile toplanmış, araştırmaya cevap veren katılımcılardan 313'ünün verileri istatistik analiz için uygun bulunmuştur. Coğrafi bölge farklılıkların dikkate alındığı araştırmalarda başka sonuçlara ulaşılması mümkündür. Belirtilmesi gereken bir diğer nokta da, araştırma verilerinin toplanması aşamasında öğretmenlerin ölçekleri doldurmadan önce fazlasıyla tükendiklerini dile getirmelerinin ardından öğretmenlik mesleğine göstermiş oldukları saygıdan dolayı mesleklerinin adını zedelememek adına sonuçların görülüp görülmeyeceğine dair sorular yöneltmiş olmalarıdır. Verilerin anonim olarak değerlendirileceği ve saklanacakları konusunda yapılan açıklamaların etkili olduğu ve buna bağlı olarak da öğretmenlerin bahsedilen endişelerinin verdikleri bilgilere yansımadığı düşünülse de, bu konunun hassasiyeti sonraki araştırmacılar tarafından göz önüne alınabilecek bir durumdur.

Öğretmenlerin Meslektaş İlişkileri İle Tükenmişlik Duygusu Arasındaki İlişki” üzerine çalışma yapacak araştırmacılar için bazı öneriler sıralanmıştır: Bu önerilerden ilki, çalışmanın daha büyük bir örnek kütle seçilerek yapılmasıdır. Böylece hem çalışma üzerinde genelleme yapılabilecek hem de daha doğru sonuçlar elde edilecektir. İkinci ise; anketin katılımcılara aynı zaman diliminde, aynı koşullarda ve aynı ortamda dağıtılmasıdır. Diğer türlü katılımcıların birbiriyle iletişim içerisinde olması, farklı koşullar altında anketi cevaplamaları sağlıklı veriler elde edilmesini engelleyebilir. Son olarak yapılan alan yazın incelemeleri neticesinde "Öğretmenlerin Meslektaş İlişkileri İle Tükenmişlik Duygusu Arasındaki İlişki" kavramlarının birlikte ele alındığı çalışmaya rastlanmamıştır. Bu açıdan bakıldığında meslektaş ilişkilerine daha iyi tanımlar getirebilmek ve araştırmak için araştırmada belirtilen kriterler göz önünde bulundurularak daha fazla çalışma yapılması gerekmektedir. Bu şekilde, sosyal bilim araştırmaları için daha kabul edilebilir çalışmalar elde edilecektir.

\section{KAYNAKÇA}

Akdağ, H., ve Güney, S. (2018, Mart). Tükenmişlik sendromunun muhasebe meslek mensupları açısından incelenmesi Erzincan ve Erzurum illerinde bir araştırma. Atatürk Üniversitesi İktisadi ve Idari Bilimler Dergisi, 32(2), 447-460.

Akıllıŏlu, F. S. (2017). Tükenmişlik ile işten ayrılma niyeti ilişkisi: kastamonu il merkezindeki banka çalı̧̧anları üzerinde bir uygulama. Yüksek Lisans Tezi, Kastamonu.

Aktaş, H., ve Şimşek, E. (2015). Bireylerin örgütsel sessizlik tutumlarında iş doyumu ve duygusal tükenmişlik algılarının rolü. Uluslararası Yönetim İktisat ve İşletme Dergisi, 11(24), 205-230.

Ardıç, K., ve Polatcı, S. (2008). Tükenmişlik sendromu akademisyenler üzerinde bir uygulama. Gazi Üniversitesi İktisadi ve İdari Bilimler Fakültesi Dergisi, 10(2), 69-96.

Bıçak, M. (2018). Diyarbakır ilinde anestezi uygulayıcılarında tükenmişlik sendromu sıklı̆̆ının araştırılması. Uzmanlık Tezi, Dicle Üniversitesi Tıp Fakültesi, Anesteziyoloji ve Reanimasyon Anabilim Dalı, Diyarbakır. 
Bitmiş, G. M., Sökmen, A. ve Turgut, H. (2013). Psikolojik dayanıklılığın tükenmişlik üzerine etkisi: örgütsel özdeşleşlmenin aracılık rolü. Gazi Üniversitesi İktisadi ve İdari Bilimler Fakültesi Dergisi, 15(2), 27-40.

Çetinkaya Ulusoy, E. (2010). Hemşirelerde meslektaş dayanışması ölçeği'nin geliştirilmesi ve meslektaş dayanışmasının iş doyumu ile ilişkisi. Doktora Tezi, Marmara Üniversitesi, Hemşirelik Esasları Anabilim Dalı, İstanbul.

Çivici, T. (2016). İş doyumu, demotivasyon faktörleri ve tükenmişlik arasındaki ilişki: mimarlar üzerinde bir araştırma. Trakya Üniversitesi Sosyal Bilimler Fakültesi, 18(2), 131-150.

Deran, A., ve Beller, B. (2015). Muhasebe meslek mensuplarında tükenmişlik Sendromu Üzerine Giresun il merkezinde yapılan bir araştırma. Erciyes Üniversitesi İktisadi ve İdari Bilimler Fakültesi Dergisi, 2(45), 69-93.

Diri, M. S. (2015). Ortaokul öğretmenlerinin iş doyumlarının mesleki tükenmişlik düzeylerine etkisi Aydın örneği. Yüksek Lisans Tezi, Adnan Menderes Üniversitesi, Sosyal Bilimler Ensititüsü, Eğitim Bilimleri Anabilim Dalı, Aydın.

Dülger, V. (2014). Tükenmişlik sendromu ve iş doyumu etkisi. Yüksek Lisans Tezi, Beykent Üniversitesi, Sosyal Bilimler Ensititüsü, İşletme ve Sağlık Kurumları Yönetimi, İstanbul.

Düz, A. G. (2015). Sağlık çalışanlarında tükenmişlik sendromunun kişilik özellikleri ile olan ilişkisi. Yüksek Lisans Tezi, Beykent Üniversitesi, Sosyal Bilimler Ensititüsü, İşletme Yönetimi Anabilim Dalı, İstanbul.

Elçikoca, G. (2018). Sağlık sektörü çalışanlarının uyku kalitesinin tükenmişlik sendromuyla ilişkisi. Yüksek Lisans Tezi, Beykent Üniversitesi, Sosyal Bilimler Enstitüsü, İşletme Yönetimi, İstanbul.

Engizek, H., Gül, N., ve Taşlıyan, M. (2017). Tükenmişlik, iş tatmini ve esnek çalışma saatleri: çalışan kadınlar üzerine bir çalışma. Türk Bilim Araştırma Vakfı, 10(2), 111-125.

Eroğlu, Ş. G. (2014). Örgütlerde duygusal emek ve tükenmişlik ilişkisi üzerine bir araştırma. Pamukkale Üniversitesi Sosyal Bilimler Enstitüsü Dergisi(19), 147-160.

Eser, Ş. (2010). Okul öncesi öğretmenlerinde iş doyumu, meslektaş ilşkileri ve okul idaresi desteğ arasındaki ilişkilerin incelenmesi Tekirdă̆ örneği. Yüksek Lisans Tezi, Çanakkale Onsekiz Mart Üniversitesi, Sosyal Bilimler Enstitüsü, Okul Öncesi Öğretmenliği Anabilim Dalı, Çanakkale.

Fettahlığlu, Ö. O. (2015). Günümüz işletmelerinin temel hastalığı: örgütsel sinizme yönelilk algılamaların, tükenmişlik boyutları üzerine etkisi. Akademik Sosyal Araştırmalar Dergisi, 3(13), 178-191.

Gülova, A. A., İspirli, D., ve Eryılmaz, İ. (2014). İş kolik ve tükenmişlik arasındaki ilişkinin incelenmesine yönelik beyaz yakalılar üzerine bir araştırma. Sosyal Bilimler Enstitüsü Dergisi, 19, 25-39.

Güney, S., ve Akdağ, H. (2018). Tükenmişlik sendromunun muhasebe meslek mensupları açısından incelenmesi Erzincan ve Erzurum illerinde bir araştırma. Atatürk Üniversitesi İktisadi ve İdari Bilimler Dergisi, 32(2), 447-460.

Gürcan, T. (2019). Hemşirelikte meslektaş dayanışmasının iş doyumu ve işten ayrılma niyetine etkisi. Yüksek Lisans Tezi, Marmara Üniversitesi, Sağlık Bilimleri Enstitüsü, Hemşirelik Anabilim Dalı, İstanbul.

Helvacı, I., ve Turhan, M. (2013). Tükenmişlik düzeylerinin incelenmesi: Silifke'de görev yapan sağlık çalışanları üzerinde bir araştırma. İşletme ve İktisat Çalışmaları Dergisi, 1(4), 58-68. 
Hertzog, H. S., Pensavalle, M. T., and Lemlech, J. K. (2000). Collegial relationships:what does it mean to be a colleague? Educational Resources Information Center, 5(1), 2-18.

İraz, R., ve Ganiyusufoğlu, A. (2011). Örgütlerde mesleki tükenmişlik ve akademisyenler üzerinde bir uygulama. SÜ İ̈BF Sosyal ve Ekonomik Araştırmalar Dergisi , 11(21), 451- 472.

Kalkızoğlu, S. (2018). Tükenmişlik sendromunun iş tatminine etkisi: perakende sektörü ve sanal örgüt çalışanlarına yönelik bir uygulama. Yüksek Lisans Tezi, Dumlupınar Üniversitesi, Sosyal Bilimler Ensititüsü, İşletme Anabilim Dalı, Kütahya.

Karakuzu, M. (2019). Beden eğitimi öğretmenlerinde iş doyumu. meslektaş ilişkileri ve okul idaresi desteğinin incelenmesi. Yüksek Lisans Tezi, Aksaray Üniversitesi, Sosyal Bilimler Enstitüsü, Beden Eğitimi ve Spor Anabilim Dalı, Aksaray.

Koç, İ. (2019). Sağllk çalş̧anlarında tŏkenmişlik sendromunun iş doyumu ve depresyonla ilişkisi. Tıpta Uzmanlık Tezi, Sağlık Bilimleri Üniversitesi Haseki Sağlık Uygulama ve Araştırma Merkezi, Sağlık Bilimleri Enstitüsü, İstanbul.

Koyuncu, N. (2015). İşyerinde psikolojik şiddetin (mobbing) tükenmişlik sendromu ile ilişkisi- bankacılık sektöründe bir araştırma. Yüksek Lisans Tezi, Kafkas Üniversitesi, Sosyal Bilimler Enstitüsü, İşletme Anabililm Dalı, Kars.

Köse, G. (2014). Örgütsel adalet algısının tükenmişlik üzerindeki etkisini belirlemeye yönelik bir araştırma. Yüksek Lisans Tezi, Hacettepe Üniversitesi, Sosyal Bilimler Ensititüsü, İşletme Anabilim Dalı, Ankara.

Murat, M. (2016). Üniversite öğretim elemanlarında tükenmişlik. Türk Psikolojik Danışma ve Rehberlik Dergisi, 11(19), 25-34.

Ören, B. (2018). Yoğun bakım ünitelerinde çalışan hemşirelerdeki tükenmişlik sendromu. Yüksek Lisans Tezi, Toros Üniversitesi, Sosyal Bilimler Enstitüsü, İşletme Anabilim Dalı, Bartın.

Özaslan Çalışkan, B. Ö. (2018). İş stresi, meslektaş ilişkileri ve bireysel performans İlişkileri: lojistik sektöründe bir araştırma. ICOAEF'18 IV. International Conference on Applied Economics and Finance Extended With Social Sciences, s. 85-92.

Özaydın, M. M., ve Özdemir, Ö. (2014). Çalışanların bireysel özelliklerinin iş tatmini üzerindeki etkileri: bir kamu bankası örneği. İşletme Araştırmaları Dergisi, 6(1), 251-281.

Tekiner Tozduman, D. (2016). Öğretmenlerin stresle baş edebilme yöntemleri ile tükenmişlik semdromu arasındaki ilişki. Yüksek Lisans Tezi, Yeditepe Üniversitesi, Eğitm Bilimleri Enstitüsü, İstanbul.

Toğa, N. (2016). Örgütsel adalet algısının tükenmişlik sendromuna etkisi ve bir uygulama. Yüksek Lisans Tezi, İnönü Üniversitesi, Sosyal Bilimler Ensititüsü, Malatya.

Turgut, F. (2014). Tükenmişlik sendromuna etki eden faktörler. Yüksek Lisans Tezi, Beykent Üniversitesi, Sosyal Bilimler Ensititüsü, İşletme Yönetimi Anabilim Dalı, İstanbul.

Yılmaz, S. E. (2018). İ̧s-aile çatışmasının, tükenmişlik ve işten ayrılma niyeti üzerindeki etkisi: sosyal normların düzenleyeci rolü. Yüksek Lisans Tezi, Niğde Halisdemir Üniversitesi, Sosyal Bilimler Enstitüsü, İşlemte Anabilim Dalı, Niğde. 